\title{
LEVEL OF TERTIARY EDUCATION IN THE EUROPEAN UNION
}

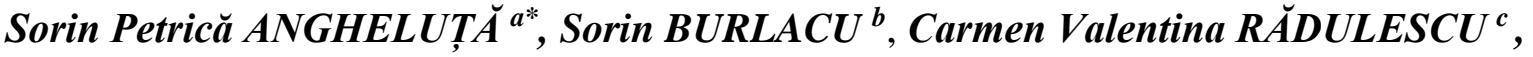 \\ Carol Cristina GOMBOS ${ }^{d}$
}

\author{
${ }^{a, b, c, d}$ Bucharest University of Economic Studies, Romania
}

\begin{abstract}
Through the skills they acquire upon graduation, higher education is increasingly important. Cooperation between different higher education institutions, as well as joint support for university programs, has contributed to increasing student mobility. The article presents an analysis of the level of tertiary education for the population of the European Union, aged between 25 and 34 years. The application of new technologies requires highly qualified people. Given the demands that will come from the labor market, higher education will need to take advantage of the opportunity to provide flexible and modular learning pathways.
\end{abstract}

KEYWORDS: European Union, tertiary education.

DOI: 10.24818/IMC/2021/02.15

\section{INTRODUCTION}

New technologies contribute to a permanent state of job change (Costache et al., 2015). Higher skills are increasingly in demand in new jobs (Androniceanu \& Burlacu, 2017). Thus, it is considered that to increase productivity, an important contribution is made by the process of increasing the level of education of members of a community (Silva et al., 2019). During the educational process, studying ways to organize resources and time can provide an advantage for tertiary level graduates in future jobs (Formanek et al., 2019).

In the context of the demand for an increase in the employment rate, participation in education and training programs contributes to achieving a balance between the skills of employees and the qualification needs of a company (Cedefop, 2018). It is considered that solving the complex problems faced by graduates in the workplace cannot be fully solved on the basis of solving approaches applied in the education process (Danaher and Schoepp, 2020).

Regarding the development of their own careers, training courses, as well as volunteering, can lead to the development of appropriate work habits, necessary for the future jobs of graduates (González et al., 2019). It can be said that, at all educational levels, within the educational process its quality is pursued (Burlacu et al., 2013). Thus, at the university level, the aim is to acquire competence regarding the ability to learn throughout life (González et al., 2019). Identifying solutions to various problems that may arise in the workplace should not lead to a decrease in compliance with the quality of the standards used (Gale and Parker, 2017). Recently, the use of laptops at work, as a resource, has been a favorable approach to the continuation of professional activities (Andrew et al., 2018).

The level of education of graduates influences employment rates. Thus, the structure of the labor market can be changed by the skills that graduates acquired during the educational processes in which they participated (EC, 2019). The higher the level of training, the better the chances of getting a better and better paid job (Burlacu \& Neagu, 2007).

\footnotetext{
* Corresponding author. E-mail address: sorin.angheluta@gmail.com
} 
After entering the labor market, further participation in education and training programs is needed to lead to the acquisition of new skills or to the updating of those skills already acquired (Stoica $\&$ Burlacu, 2017). The more relevant the skills, knowledge and abilities, the higher the degree of employment in the labor market. In this way, personal fulfillment, as well as social and professional fulfillment, can be based on sound skills and knowledge of the highest level (Radulescu et al., 2021).

At the level of the European Union, it is desired that by 2030 over $50 \%$ of the population between 30 and 34 years to be in the category of tertiary education graduates. Thus, given that future entrepreneurs are being prepared at this level, in the next period education systems will pay additional attention to tertiary education (EC, 2020).

\section{RESULTS AND DISCUSSIONS}

The study started by analyzing the evolution of the population aged between 25 and 34 years. Thus, the evolution of the population in the member countries of the European Union, aged between 25 and 34, for the period 2013-2020, is presented in the following table.

Table 1. Evolution of the population in the member countries of the European Union, aged between 25 and 34, for 2013-2020 (Thousand)

\begin{tabular}{|c|c|c|c|c|c|c|c|c|}
\hline Countries & 2013 & 2014 & 2015 & 2016 & 2017 & 2018 & 2019 & 2020 \\
\hline Belgium & $1.432,5$ & $1.437,6$ & $1.444,6$ & $1.450,9$ & $1.452,3$ & $1.466,1$ & $1.473,1$ & $1.477,7$ \\
\hline Bulgaria & 989 & 980,4 & 968,9 & 956,8 & 937,0 & 913,8 & 885,8 & 852,5 \\
\hline Czechia & $1.504,4$ & $1.462,8$ & $1.436,0$ & $1.420,1$ & $1.407,0$ & $1.395,3$ & $1.381,9$ & $1.357,8$ \\
\hline Denmark & 650,7 & 659,6 & 671,7 & 692,2 & 713,0 & 730,8 & 750,0 & 762,1 \\
\hline Germany & $9.783,9$ & $10.023,5$ & $10.177,3$ & $10.562,8$ & $10.570,6$ & $10.385,6$ & $10.335,2$ & $10.471,9$ \\
\hline Estonia & 186,9 & 188,6 & 190,4 & 192,9 & 191,5 & 190,7 & 187,4 & 182,9 \\
\hline Ireland & 709,8 & 686,2 & 666,7 & 654,9 & 639,0 & 625,3 & 619,1 & 614,7 \\
\hline Greece & $1.460,6$ & $1.416,9$ & $1.368,3$ & $1.322,0$ & $1.278,6$ & $1.232,9$ & $1.192,4$ & $1.167,7$ \\
\hline Spain & $6.352,4$ & $6.016,6$ & $5.766,3$ & $5.522,6$ & $5.369,2$ & $5.307,4$ & $5.290,3$ & $5.270,4$ \\
\hline France & $7.699,3$ & $7.935,5$ & $7.906,2$ & $7.842,1$ & $7.768,4$ & $7.721,2$ & $7.652,6$ & $7.588,2$ \\
\hline Croatia & 571,9 & 565,3 & 550,3 & 538,9 & 527,6 & 516,5 & 505,6 & 495,0 \\
\hline Italy & $6.996,3$ & $6.910,5$ & $6.837,4$ & $6.760,8$ & $6.677,2$ & $6.607,8$ & $6.532,9$ & $6.453,2$ \\
\hline Cyprus & 143,2 & 141,5 & 138,0 & 137,1 & 141,0 & 141,7 & 144,3 & 148,4 \\
\hline Latvia & 276,9 & 276,2 & 275,3 & 273,6 & 268,1 & 262,4 & 254,1 & 244,0 \\
\hline Lithuania & 370,3 & 370,7 & 373,3 & 374,8 & 371,0 & 371,1 & 371,6 & 373,7 \\
\hline Luxembourg & 75,8 & 77.6 & 82.7 & 85.4 & 87.9 & 90.1 & 93.0 & 96.0 \\
\hline Hungary & $1.291,9$ & $1.255,0$ & $1.227,7$ & $1.215,4$ & $1.206,0$ & $1.209,0$ & $1.218,0$ & $1.222,5$ \\
\hline Malta & 62 & 64.7 & 68.1 & 71.3 & 75.8 & 82.2 & 89.4 & 92.1 \\
\hline Netherlands & $2.039,3$ & $2.043,1$ & $2.046,7$ & $2.078,8$ & $2.122,6$ & $2.157,4$ & $2.189,4$ & $2.215,0$ \\
\hline Austria & $1.104,5$ & & & $1.175,5$ & $1.181,5$ & $1.183,2$ & $1.187,2$ & $1.189,3$ \\
\hline Poland & $5.682,9$ & $5.585,6$ & $5.518,5$ & $5.450,2$ & $5.341,4$ & $5.168,5$ & $4.991,2$ & $4.840,5$ \\
\hline Portugal & $1.292,6$ & $1.245,5$ & $1.211,2$ & $1.180,4$ & $1.148,8$ & $1.124,4$ & $1.111,9$ & $1.111,6$ \\
\hline Romania & $2.796,4$ & $2.771,7$ & $2.749,3$ & $2.669,3$ & $2.574,0$ & $2.519,7$ & $2.467,5$ & $2.402,5$ \\
\hline Slovenia & 288,9 & 286,8 & 281,8 & 265,6 & 260,8 & 253,7 & 248,2 & 244,6 \\
\hline Slovakia & 881,7 & 867,1 & 851,1 & 840,5 & 829,5 & 815,4 & 800,4 & 779,2 \\
\hline Finland & 687,6 & 691,2 & 696,3 & 701,1 & 704,7 & 706,2 & 705,8 & 707,0 \\
\hline Sweden & $1.214,8$ & $1.248,2$ & $1.281,3$ & $1.324,6$ & $1.374,9$ & $1.413,3$ & $1.443,1$ & $1.457,0$ \\
\hline United Kingdom & $8.580,8$ & $8.657,3$ & $8.735,1$ & $8.816,5$ & $8.866,8$ & $8.916,0$ & $8.945,1$ & \\
\hline
\end{tabular}

Source: made by the authors based on existing data on the EUROSTAT website (2021) 
Compared to 2013, in 2020 it is found that the countries with the largest population declines aged between 25 and 34 are: Spain (-1.082 thousand people), Poland (-842,4 thousand people), Italy (-543,1 thousand people), Romania (393,9 thousand people), Greece (-292,9 thousand people), Portugal (-181 thousand people), Czechia (-146,6 thousand people), Bulgaria (-136,5 thousands people). For the same period, in some countries the population aged 25 to 34 has increased. This is the case: Germany (+688 thousand people), United Kingdom (+364,3 thousand people in 2019), Sweden (+242,2 thousand people), Netherlands (+175,7 thousand people), Denmark $(+111,4$ thousand people), Austria ( +84.8 thousand people).

In 2020, the countries with the most people in this age group were: Germany (10.471,9 thousand people), France (7.588,2 thousand people), Italy (6.453,2 thousand people), Spain (5.270,4 thousands people), Poland (4.840,5 thousand people), Romania (2.402,5 thousand people), Netherlands (2.215 thousand people). The youngest people in the age group 25-34 were in: Malta (92,1 thousand people), Luxembourg (96 thousand people), Cyprus (148,4 thousand people), Estonia (182,9 thousand people), Latvia (244 thousand people), Slovenia (244,6 thousand people), Lithuania (373,7 thousand people).

The evolution at the level of the European Union of the population in the age group 25-34 years, for the period 2013-2019, is shown in the following figure.

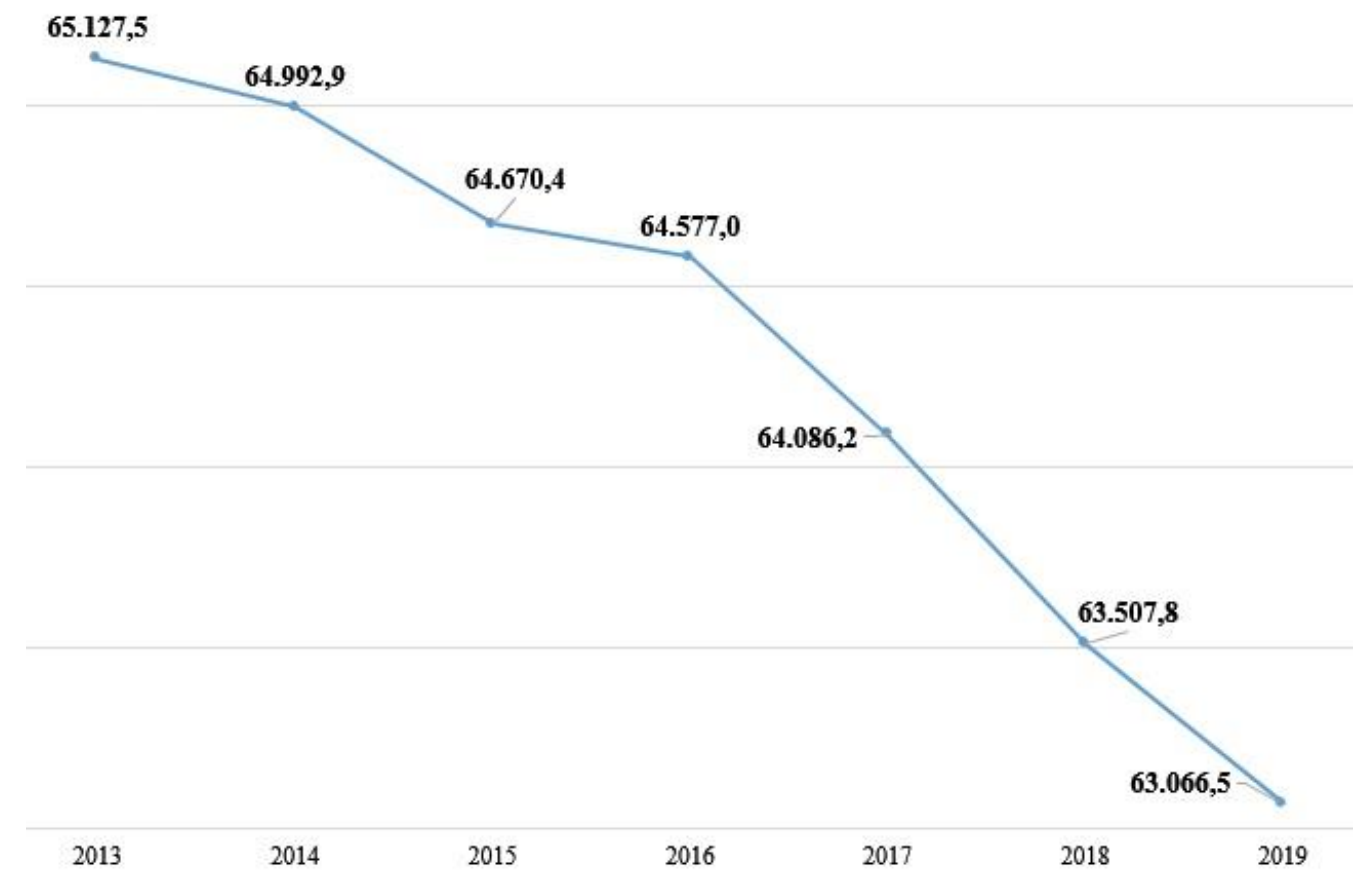

Figure 1. Evolution at the level of the European Union of the population in the age group 25-34 years, for the period 2013-2019 (Thousand)

Source: made by the authors based on existing data on the EUROSTAT website (2021)

From the data presented, it is observed that compared to 2013, in 2019 the population of the European Union, aged between 25 and 34, decreased by 2061 thousand people. The trend is one of declining population in this age group.

The share of the population in the age group 25-34 years (of the total population in this age group), who graduated from tertiary education is presented in the following table.

The countries where the share of the population with tertiary education level, in the age group 25-34, has increased the most are: Ireland (+27.8\%), Cyprus $(+25.1 \%)$, Latvia $(+26.9 \%)$, Luxembourg $(+37.7 \%)$, Malta $(+31.4 \%)$, the Netherlands $(+25.4 \%)$, Poland $(+28.1 \%)$, Portugal $(+29.1 \%)$, Slovenia $(+26.1 \%)$, Slovakia $(+27.9 \%)$. For the same period, the share of the population 
with tertiary education level, in the age group 25-34 years, decreased in: Belgium (-12.5\%), Bulgaria (-14.1\%), Germany (-12.7\%), Estonia (-14.7\%), Spain (13.5\%).

Table 2. Comparative situation of the share of the population in the age group 25-34 years tertiary educational attainment $(\%)$

\begin{tabular}{|l|r|r|r|r|r|r|}
\hline Countries & $\mathbf{2 0 0 0}$ & $\mathbf{2 0 0 4}$ & $\mathbf{2 0 0 8}$ & $\mathbf{2 0 1 2}$ & $\mathbf{2 0 1 6}$ & $\mathbf{2 0 2 0}$ \\
\hline Belgium & 36.0 & 40.7 & 42.3 & 43.0 & 44.3 & 48.5 \\
\hline Bulgaria & 18.9 & 24.3 & 26.0 & 27.2 & 32.8 & 33.0 \\
\hline Czechia & 11.7 & 12.9 & 17.7 & 27.8 & 32.6 & 33.0 \\
\hline Denmark & 28.9 & 37.6 & 36.2 & 40.2 & 44.6 & 47.1 \\
\hline Germany & 22.4 & 22.9 & 23.9 & 28.9 & 30.5 & 35.1 \\
\hline Estonia & 28.4 & 27.7 & 35.8 & 40.1 & 41.2 & 43.1 \\
\hline Ireland & 30.6 & 40.1 & 47.2 & 50.3 & 54.3 & 58.4 \\
\hline Greece & 23.3 & 24.8 & 27.7 & 34.5 & 41.0 & 43.7 \\
\hline Spain & 33.9 & 39.0 & 40.0 & 40.4 & 41.0 & 47.4 \\
\hline France & 31.4 & 38.5 & 40.6 & 42.6 & 44.2 & 49.4 \\
\hline Croatia & $:$ & 17.4 & 19.9 & 23.6 & 32.8 & 36.6 \\
\hline Italy & 10.6 & 14.7 & 19.9 & 22.5 & 25.6 & 28.9 \\
\hline Cyprus & 32.7 & 42.7 & 48.0 & 53.6 & 56.2 & 57.8 \\
\hline Latvia & 17.3 & 19.7 & 28.8 & 38.7 & 42.1 & 44.2 \\
\hline Lithuania & 39.9 & 35.7 & 41.5 & 48.6 & 54.9 & 56.2 \\
\hline Luxembourg & 22.9 & 32.4 & 38.7 & 49.9 & 51.5 & 60.6 \\
\hline Hungary & 14.6 & 18.9 & 24.1 & 30.5 & 30.4 & 30.7 \\
\hline Malta & 8.8 & 18.4 & 23.1 & 28.3 & 34.3 & 40.2 \\
\hline Netherlands & 26.9 & 34.5 & 38.3 & 414 & 45.2 & 52.3 \\
\hline Austria & $:$ & 20.1 & 19.2 & 22.8 & 39.7 & 41.4 \\
\hline Poland & 14.3 & 23.0 & 32.1 & 40.8 & 43.5 & 42.4 \\
\hline Portugal & 12.8 & 18.4 & 23.2 & 29.0 & 35.0 & 41.9 \\
\hline Romania & 9.2 & 12.6 & 18.8 & 23.6 & 24.8 & 24.9 \\
\hline Slovenia & 19.3 & 24.9 & 30.0 & 35.3 & 43.0 & 45.4 \\
\hline Slovakia & 11.1 & 14.3 & 18.4 & 27.0 & 33.4 & 39.0 \\
\hline Finland & 37.8 & 38.2 & 38.3 & 39.7 & 40.7 & 43.8 \\
\hline Sweden & 33.1 & 34.5 & 40.9 & 43.5 & 47.3 & 49.2 \\
\hline United Kingdom & 31.5 & 35.5 & 38.6 & 45.1 & 47.1 & 49.4 \\
\hline
\end{tabular}

Source: made by the authors based on existing data on the EUROSTAT website (2021)

In 2020, the highest values are recorded in: Belgium (48.5\%), Ireland (58.4\%), France (49.4\%), Cyprus (57.8\%), Lithuania (56.2\%), Luxembourg (60.6\%), the Netherlands $(52.3 \%)$, Sweden $(49.2 \%)$. At the same time, the lowest values of the share of the population with tertiary education level, in the age group 25-34 years, were in: Romania (24.9\%), Italy (28.9\%), Hungary (30.7\% ).

The evolution of this indicator for the countries of the European Union is presented in the following figure.

From the presented data, it is observed the increase of the share of the population with tertiary education level, from the age group 25-34 years. The increase is highlighted both for the total population and for the male and female population, respectively. 


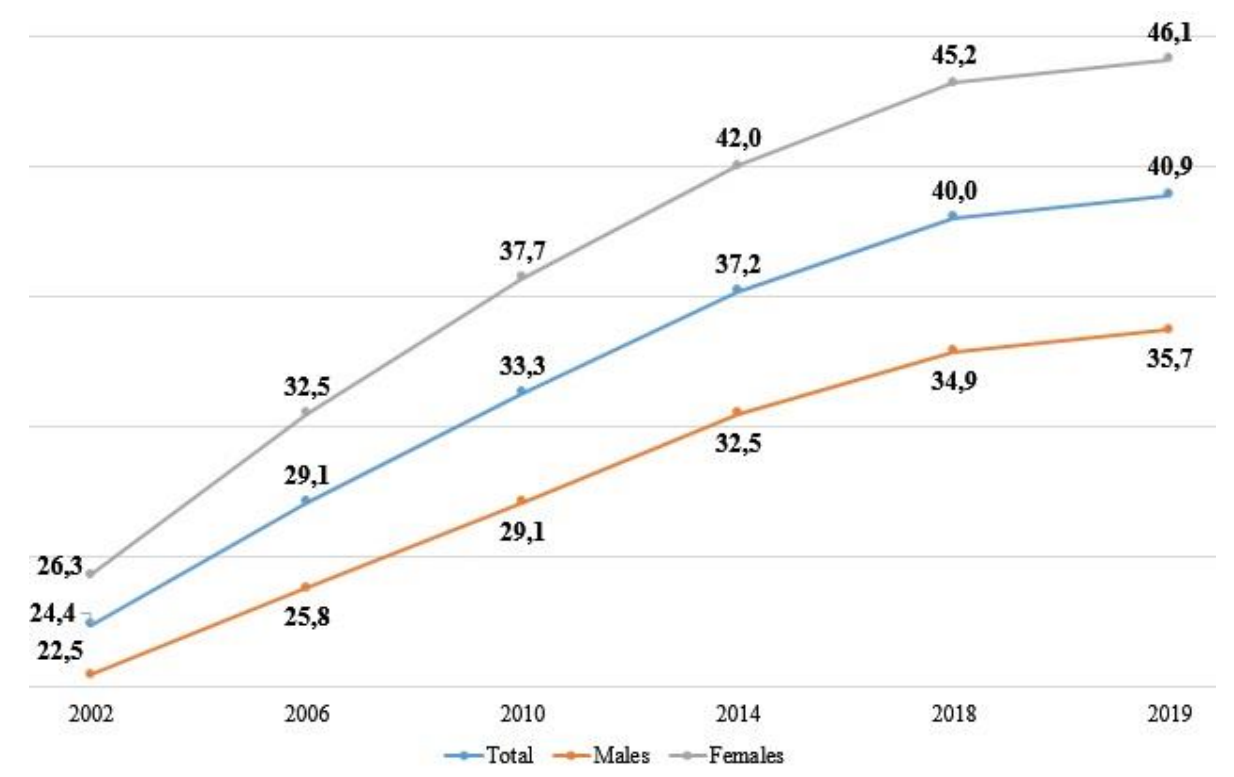

Figure 2. The evolution of the share of the population in the age group 25-34 years tertiary educational attainment, for the countries of the European Union (\%)

Source: made by the authors based on existing data on the EUROSTAT website (2021)

After graduating from tertiary education, an important moment is employment. The following table presents the comparative situation of employment rates for the age groups 25-29 years, respectively 30-34 years. The comparative analysis was performed for 2013 and 2020.

Table 3. The comparative situation of employment rates for the age groups 25-29 years, respectively 30-34 years, for 2013 and $2020(\%)$

\begin{tabular}{|c|c|c|c|c|}
\hline \multirow[b]{2}{*}{ Countries } & \multicolumn{2}{|c|}{ From 25 to 29 years } & \multicolumn{2}{|c|}{ From 30 to 34 years } \\
\hline & 2013 & 2020 & 2013 & 2020 \\
\hline Belgium & 83.6 & 83.8 & 89.9 & 89.9 \\
\hline Bulgaria & 73.6 & 83.3 & 84.2 & 89.2 \\
\hline Czechia & 77.6 & 75.8 & 78.4 & 76.8 \\
\hline Denmark & 78.5 & 79.9 & 89.9 & 89.1 \\
\hline Germany & 86.6 & 85.4 & 89.6 & 89.9 \\
\hline Estonia & 78.3 & 83.7 & 78.2 & 78.9 \\
\hline Ireland & 79.8 & 83.7 & 85.1 & 87.8 \\
\hline Greece & 53.0 & 63.6 & 70.8 & 76.6 \\
\hline Spain & 65.8 & 70.2 & 77.7 & 79.5 \\
\hline France & 83.7 & 83.1 & 88.1 & 87.2 \\
\hline Croatia & 68.7 & 75.8 & 84.3 & 88.4 \\
\hline Italy & 50.2 & 55.3 & 76.2 & 78.3 \\
\hline Cyprus & 72.9 & 82.3 & 85.2 & 86.9 \\
\hline Latvia & 85.0 & 80.0 & 87.6 & 89.2 \\
\hline Lithuania & 88.5 & 89.2 & 92.1 & 91.2 \\
\hline Luxembourg & 78.7 & 83.5 & 90.0 & 87.9 \\
\hline Hungary & 80.8 & 83.4 & 79.4 & 80.3 \\
\hline Malta & 92.3 & 93.6 & 94.0 & 92.5 \\
\hline Netherlands & 88.7 & 90.5 & 91.9 & 92.7 \\
\hline Austria & 84.0 & 82.6 & 87.6 & 89.6 \\
\hline Poland & 80.2 & 85.9 & 88.4 & 90.8 \\
\hline Portugal & 71.0 & 80.4 & 81.3 & 88.2 \\
\hline Romania & 79.3 & 86.9 & 92.4 & 91.3 \\
\hline Slovenia & 76.5 & 86.4 & 89.1 & 92.5 \\
\hline Slovakia & 72.0 & 76.8 & 79.9 & 77.8 \\
\hline Finland & 82.7 & 86.5 & 82.4 & 84.7 \\
\hline Sweden & 82.5 & 82.6 & 90.1 & 88.0 \\
\hline United Kingdo & 87.2 & & 88.7 & \\
\hline
\end{tabular}

Source: made by the authors based on existing data on the EUROSTAT website (2021) 
From the presented data it is observed that in 2020, for people in the age group 30-34 years, who have the level of tertiary education, employment rates were over $90 \%$ in 6 countries (Netherlands 92.7\%, Malta - 92.5\%, Slovenia - 92.5\%, Romania - 91.3\%, Lithuania - 91.2\%, Poland - 90.8\%). In 2020, for people in the age group 25-29, who have a tertiary education level, employment rates were high in: Malta (93.6\%), the Netherlands (90.5\%), Lithuania (89.2\%), Romania (86.9\%), Finland (86.5\%), Slovenia (86.4\%), Poland (85.9\%). For this age group (25-29 years), in 2020 compared to 2013 significant increases in employment rates are recorded in: Greece $(+10.6 \%)$, Slovenia (+9.9\%), Bulgaria (+9.7\%), Portugal $(+9.4 \%)$. Also, the values decreased for: Latvia ($5 \%)$, Czech Republic (-1.8\%), Austria (-1.4\%), Germany (-1.2\%), France (-0.6\%). In 2020, for the 25-29 age group, the lowest employment rates are recorded in: Italy (55.3\%), Greece (63.6\%), Spain $(70.2 \%)$.

For the age group 30-34 years, in 2020 compared to 2013 significant increases in employment rates are recorded in: Portugal $(+6.9 \%)$, Greece $(+5.8 \%)$, Bulgaria $(+5 \%)$, Croatia $(+4.1 \%)$, Slovenia $(+3.4 \%)$. For this age group, in 2020, the lowest employment rates are recorded in: Greece (76.6\%), Czechia (76.8\%), Slovakia (77.8\%), Italy (78.3\%), Estonia (78.9\%).

For the European Union, the evolution of employment rates in the period 2013-2019 is presented in the following figure.
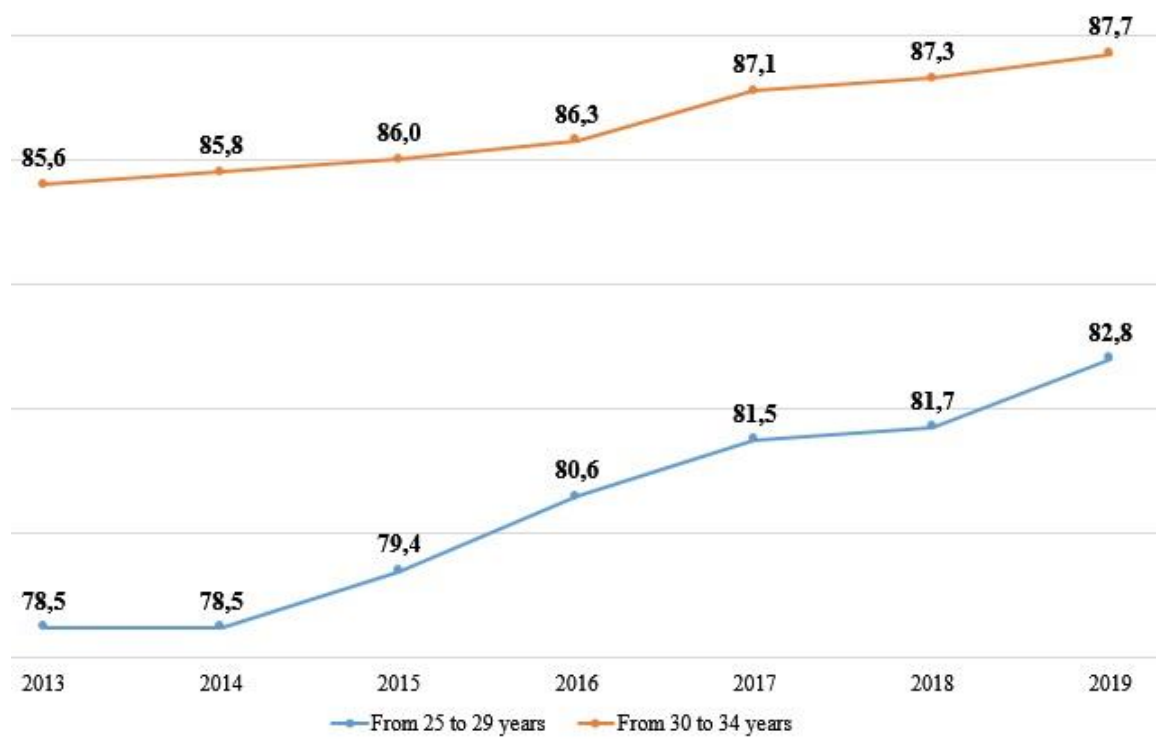

Figure 3. The evolution of employment rates in European Union, 2013-2019 (\%)

Source: made by the authors based on existing data on the EUROSTAT website (2021)

It is observed that the trends are increasing. The values are higher for the age group 30-34 years, but the increases are wider for the age group $25-29$ years (from $78.5 \%$ to $82.8 \%$ ).

\section{CONCLUSIONS}

From the analysis performed, at the level of the European Union, it is found that the number of people in the age group 25-34 years is decreasing. Regarding the level of tertiary education, at European level, the trend is to increase the share of the population in the age group 25-34 years with a level of tertiary education. In 2020, more than half of the population aged between 25 and 34 has a tertiary education level in: Luxembourg, Ireland, Cyprus, Lithuania, Netherlands.

Also, both for people in the age group 25-29 years, and for people in the age group 30-34 years, who have the level of tertiary education, employment rates have an increasing trend. 
Social and economic characteristics influence the training needs of pupils and students. Thus, the performance of graduates in future jobs depends on the quality of the education process they have had. Also, the degree of adaptation to possible future changes in the labor market is higher if graduates have acquired social, civic and entrepreneurial skills (OECD, 2019).

\section{REFERENCES}

Andrew, M., Taylorson, J., Langille, D. J., Grange, A., \& Williams, N. (2018). Student attitudes towards technology and their preferences for learning tools/devices at two universities in the UAE. Journal of Information Technology Education: Research, 17, 309-344.

Androniceanu, A., \& Burlacu, S. (2017). Intelligent system for assessment and grading based on docimologic tests. E-Learning \& Software for Education, 2.

Burlacu, S., \& Neagu, C. (2007) E-learning or electronic systems of training. management and marketing, 823.

Burlacu, S., Grigorescu, S. D., Stefan, C., \& Popescu, C. (2013). Basics of design and testing of a digital content generator tool for E-learning. In 2013 8th International Symposium On Advanced Topics In Electrical Engineering (ATEE) (pp. 1-4). IEEE.

Costache, G., Marinas, C. V., Igret, R., \& Burlacu, S. (2015). Internship in the HR Department-Organizational and Individual Perspectives. In Proceedings of the International Management Conference (Vol. 9, No. 1, pp. 359-370). Bucharest, Romania.

Danaher, M., \& Schoepp, K. (2020). Effective assessment of workplace problem-solving in higher education. Journal of Information Technology Education: Research, 19, 1-16.

European Centre for the Development of Vocational Training (Cedefop) (2018). From long-term unemployment to a matching job: the role of vocational training in sustainable return to work. Luxembourg: Publications Office. Retrieved June 20, 2021, from: https://www.cedefop.europa.eu/files/3076_en.pdf

European Commission (2019). Reflection Paper - Towards a Sustainable Europe by 2030. Retrieved June 23, 2021, from: https://ec.europa.eu/commission/publications/reflection-paper-towards-sustainable-europe2030_en.

European Commission (2020). Communication on achieving the European Education Area by 2025. Retrieved June 29, 2021, from: https://eur-lex.europa.eu/legal-content/EN/TXT/?uri=CELEX\%3A52020DC0625.

EUROSTAT. (2021). http://ec.europa.eu/eurostat

Gale, T., \& Parker, S. (2017). Retaining students in Australian higher education: cultural capital, field distinction. European Educational Research Journal, 16(1), 80-96.

Negescu, M. D., Burlacu, S., Mitriţă, M., \& Buzoianu, O. C. A. Managerial Analysis of Factoring at the International Level Challenges of the Contemporary Society. Proceedings; Cluj-Napoca Vol. 13, Iss. 1 , 99-102. Cluj-Napoca: Babes Bolyai University. (2020)

Organization for Economic Cooperation and Development (2019). Trends Shaping Education 2019, OECD Publishing, Paris. Retrieved June 20, 2021, from: https://read.oecd-ilibrary.org/education/trends-shapingeducation-2019_trends_edu-2019-en

Pereira González, M., Martís Flórez, R., \& Pascual Díez, J. (2019). Evaluation of career guidance and career education needs in six University Degrees on Education. Bases for the development of the Tutorial Action Plan. Educación XX1, 22(2), 309-334.

Radulescu, C. V., Ladaru, G. R., Burlacu, S., Constantin, F., Ioanăş, C., \& Petre, I. L. (2021) Impact of the COVID-19 Pandemic on the Romanian Labor Market. Sustainability, 13, 271. https://doi.org/10.3390/su13010271

Silva, C. S. P. C. O., Freire-Seoane, M. J., \& López-Bermúdez, B. (2019). Un análisis de la formación terciaria entre los trabajadores dependientes e independientes: El caso de Portugal. Archivos Analíticos de Políticas Educativas, 27(46).

Stoica, M. M., \& Burlacu, S. (2017). Concepts and trends on e-learning in Romania. The International Journal of Engineering And Science (IJES), 6(3), 100-105, ISSN (e): 2319 - 1813 ISSN (p): 2319-1805 